\title{
IMPLEMENTASI WAKAF TUNAI DI MASJID DARUSH SHOLIKHIN KOTA BATU
}

\author{
Ira Chandra Puspita \\ Hukum Bisnis Syari'ah UIN Maulana Malik Ibrahim Malang \\ Jl. Gajayana No. 50 Malang \\ email : aishkhuw@gmail.com
}

\begin{abstract}
Abstrak
This writing aims at identifying problems that emerged in cash waqaf in Darush Sholikhin Mosque Batu and to understand about cash waqf mechanism and its adjustments according to the Indonesian law. Nadzir of Darush Sholikhin Mosque applied effectiveness approach in using cash waqf result, namely waqaf fund. This waqf was directly used to build the Mosque. The implementation of cash waqaf in Darush Sholikhin is a form of traditional waq which is not accommodated in UUW and PP Number 42, 2006 regulating cash waqaf implementation as investment that must be implemented through Shari'ah Financial Institutions (LKS) pointed by Minister. Although the base of its implementation still refers to cash waqaf books issued by Division of Waqaf, Department of Religious Affairs of Indonesia, its implementation has not fulfilled the requirements as stated in cash waqf regulation. Nonetheless, it is implementation is appropriate with figh wakaf that is lawful in Islamic perspective.

Tulisan ini bertujuan untuk mengidentifikasi masalah yang muncul pada wakaf tunai di Masjid Darush Sholikhin Batu dan memahami mekanisme wakaf tunai berikut kesesuaiannya dengan peraturan perundangan yang berlaku di Indonesia. Nadzir masjid Darush Sholikhin menerapkan pendekatan efektifitas pemanfaatan hasil dari wakaf tunai. Dana wakafyang diterima diwujudkan secara langsung dalam pembangunan masjid tersebut. Pelaksanaan wakaf tunai di Darush Sholikhin merupakan pelaksanaan wakaf tradisional yang tidak terakomodir oleh UUW dan PP No. 42 tahun 2006, yang mengatur mengenai pelaksanaan wakaf tunai sebagai investasi yang harus dilakukan melalui LKS yang ditunjuk oleh menteri. Meskipun dasar pelaksanaannya masih berpedoman pada buku-buku tentang wakaf tunai yang dikeluarkan oleh Direktorat Pemberdayaan Wakaf, Departemen Agama Republik Indonesia, pelaksanaannya tidak memenuhi ketentuan dalam perundang-undangan tentang pelaksanaan wakaf tunai. Akan tetapi, pelaksanaannya sesuai dengan ketentuan Fiqh wakaf sehingga sah hukumnya dalam perspektif Islam.
\end{abstract}

Kata kunci : implementasi, wakaf tunai, masjid Darush Sholikhin.

Pada masa Dinasti Ayyubiyah di Mesir, perkembangan wakaf dirasa sangat menggembirakan. Pada masa ini wakaf tidak hanya sebatas benda tidak bergerak, tetapi juga benda bergerak semisal wakaf tunai. ${ }^{1}$ Selain memanfaatkan wakaf untuk kesejahteraan umat, Dinasti Ayyubiyah juga memanfaatkan wakaf untuk kepentingan politiknya dan misi alirannya, yaitu aliran sunni. Dinasti Mamluk dapat mengembangkan wakaf dengan pesat, dengan adanya kebijakan bahwa apa saja boleh diwakafkan dengan syarat dapat diambil manfaatnya. Pada masa ini, tanah pertanian dan bangunan yang banyak diwakafkan. Wakaf budak pernah dilakukan oleh penguasa Dinasti Ustmani ketika menaklukkan Mesir, wakaf budak tersebut ditujukan untuk merawat masjid. $^{2}$

Wakaf tunai merupakan suatu bentuk investasi tunai yang diberikan kepada muwaqif untuk tujuan mengharapkan ridho Allah semata. Wakaf mengalami perkembangan dengan berbagai inovasi yang signifikan seiring perkembangan zaman. Bagi masyarakat Indonesia, konsep wakaf tunai bisa dikatakan masih relatif baru. Hal ini bisa dilihat dari peraturan-peraturan yang melandasinya, yaitu fatwa 
MUI yang disahkan pada tahun 2002 dan undangundang tentang wakaf yang disahkan pada 27 Oktober 2007 oleh Presiden Susilo Bambang Yudhoyono ${ }^{3}$. Secara ekonomi, wakaf tunai sangat potensial untuk dikembangkan di Indonesia, karena model wakaf ini memiliki daya jangkau yang lebih merata kepada anggota masyarakat dibandingkan dengan modelmodel wakaf tradisional-konvensional, yaitu dalam bentuk harta fisik yang biasanya dilakukan oleh keluarga yang terbilang mampu (kaya).

Pada dasarnya, pembahasan mengenai wakaf berasal dari ajaran Islam yang diadopsi dalam hukum positif Indonesia. Pengertian wakaf secara bahasa adalah al habs yang artinya menahan. Kata al-waqf adalah bentuk masdar dari ungkapan waqfu al syai' yang berarti menahan sesuatu. ${ }^{4}$ Mengenai pengertian wakaf secara istilah, para ulama berbeda pendapat dalam penentuannya, juga mengenai tata cara perwakafan. Menurut pengikut madzhab Syafi'i, dari pendapat beberapa ulama dalam madzhab ini, Muhammad Abid Abdullah Al Kabisi mengasumsikan bahwa titik persamaan dari definisidefinisi yang ada tersebut adalah pendapat Syaikh Al Qalyubi yang mengatakan bahwa wakaf adalah "habsul maali yumkinu al intifa'u bihi ma'a baqaa'i ainihi 'ala mashrafin mubahin", artinya "menahan harta yang bisa diambil manfaatnya dengan menjaga bentuk aslinya untuk disalurkan kepada jalan yang diperbolehkan". ${ }^{5}$

Menurut madzhab Hanafi, menahan suatu benda yang menurut hukum tetap milik waqif dalam rangka menggunakan manfaatnya untuk kebajikan. Pengikut madzhab Maliki menyatakan bahwa wakaf itu tidak melepaskan harta yang diwakafkan dari kepemilikan waqif namun mencegah waqif melakukan tindakan yang dapat melepas kepemilikannya atas harta tersebut kepada orang lain, dan waqif diwajibkan untuk menyedekahkan manfaatnya dan tidak boleh menarik kembali wakafnya. Menurut pendapat pengikut madzhab Hambali, wakaf adalah melepas harta yang telah diwakafkan dari kepemilikan waqif setelah sempurna prosedur perwakafannya. ${ }^{6}$

Dalam peristilahan syara' secara umum, wakaf adalah suatu pemberian yang pelaksanaannya dilakukan dengan jalan menahan kepemilikan asal

\footnotetext{
3 Direktorat Pemberdayaanan Wakaf, Strategi Pengembangan Wakaf Tunai di Indonesia (Jakarta : Departemen Agama RI, 2008), h. 8.

4 Muhammad Abid Abdullah Al Kabisi, Hukum Wakaf(Jakarta : IlMan, 2003), h. 37-38.

5 Al Kabisi, Hukum, h. 41

6 Direktorat Pemberdayaan Wakaf, Paradigma Baru Wakaf di Indonesia (Jakarta : Departemen Agama RI, 2007), h. 2-4.
}

(tahbisul ashli) lalu menjadikan manfaatnya berlaku umum. Yang dimaksud dengan tahbisul ashli adalah menahan barang yang diwakafkan tersebut agar tidak diwariskan, dijual, dihibahkan, disewakan, digadaikan dan sebagainya. Sedangkan pemanfaatannya adalah menggunakan sesuai dengan kehendak pemberi wakaf (waqif) tanpa pemberian imbalan. ${ }^{7}$ Menurut para ulama madzhab, kecuali madzhab Maliki, berpendapat bahwa wakaf dianggap benar-benar terjadi apabila benda yang diwakafkan berlaku untuk selama-lamanya dan terus-menerus ${ }^{8}$ sehingga wakaf sering disebut sebagai amal jariyyah. Wakaf dianggap sah apabila benda yang diwakafkan tersebut merupakan benda yang dimiliki oleh waqif secara sempurna.

Dalam Inpres No. 1 tahun 1974 atau Kompilasi Hukum Islam (KHI), dinyatakan wakaf adalah perbuatan hukum seseorang atau kelompok orang atau badan hukum yang memisahkan sebagian dari benda miliknya dan melembagakannya untuk selama-lamanya guna kepentingan ibadah atau keperluan umum lainnya sesuai dengan ajaran Islam. ${ }^{9}$ Sedangkan pada Undang-undang nomer 41 tahun 2004 tentang wakaf, dinyatakan bahwa wakaf adalah perbuatan hukum waqif untuk memisahkan dan/atau menyerahkan sebagian harta benda miliknya untuk dimanfaatkan selamanya atau untuk jangka waktu tertentu sesuai dengan kepentingannya guna keperluan ibadah dan/atau kesejahteraan umum menurut syariah. ${ }^{10}$ Dalil yang menjadi dasar disyariatkannya ibadah wakaf bersumber dari ayat-ayat Al Qur'an dan Sunnah Rasulullah SAW:11

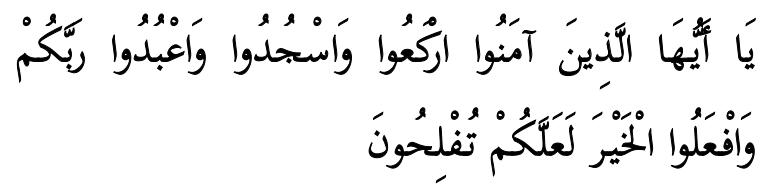

"Hai orang-orang yang beriman, rukuklah kamu, sujudlah kamu, sembahlah Tuhanmu dan perbuatlah kebajikan, supaya kamu mendapat kemenangan."(Surat Al Hajj : 77)

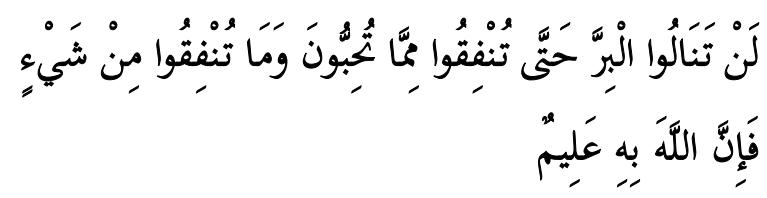

7 Direktorat Pemberdayaan Wakaf, Paradigma, h. 1.

8 Direktorat Pemberdayaan Wakaf, Paradigma, h. 4-6

9 KHI, pasal 215 ayat (1)

10 Undang-undang No. 41 tahun 2004 tentang wakaf, pasal 1 angka 1

11 Direktorat Pemberdayaan Wakaf, Fiqh Wakaf (Jakarta : Departemen Agama RI, 2007), h. 12-13. 
"Kamu sekali-kali tidak sampai kepada kebajikan (yang sempurna), sebelum kamu menafkahkan sebagian harta yang kamu cintai. Dan apa saja yang kamu nafkahkan, maka sesungguhnya Allah mengetahuinya." (Surat Ali Imron : 92)

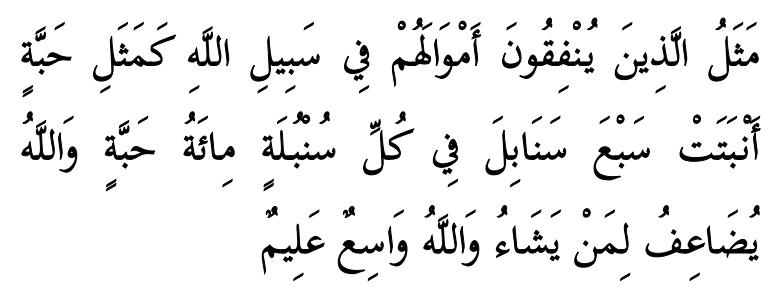

"Perumpamaan (nafkah yang dikeluarkan oleh) orang-orang yang menafkahkan hartanya di jalan Allah adalah serupa dengan sebutir benih yang menumbuhkan tujuh bulir, pada tiap-tiap bulir: seratus biji. Allah melipat gandakan (ganjaran) bagi siapa yang Dia kehendaki. Dan Allah Maha Luas (karunia-Nya) lagi Maha Mengetahui." (surat Al Baqarah: 261)

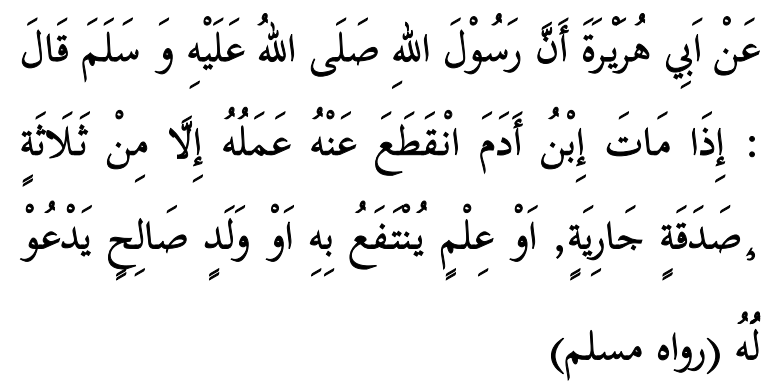

"Dari Abu Hurairah ra, sesungguhnya Rasulullah SAW bersabda, "Apabila anak Adam (manusia) meninggal dunia, maka putuslah amalnya kecuali tiga perkara : shadaqah jariyah, ilmu yang bermanfaat dan anak sholeh yang mendoakan orang tuanya."

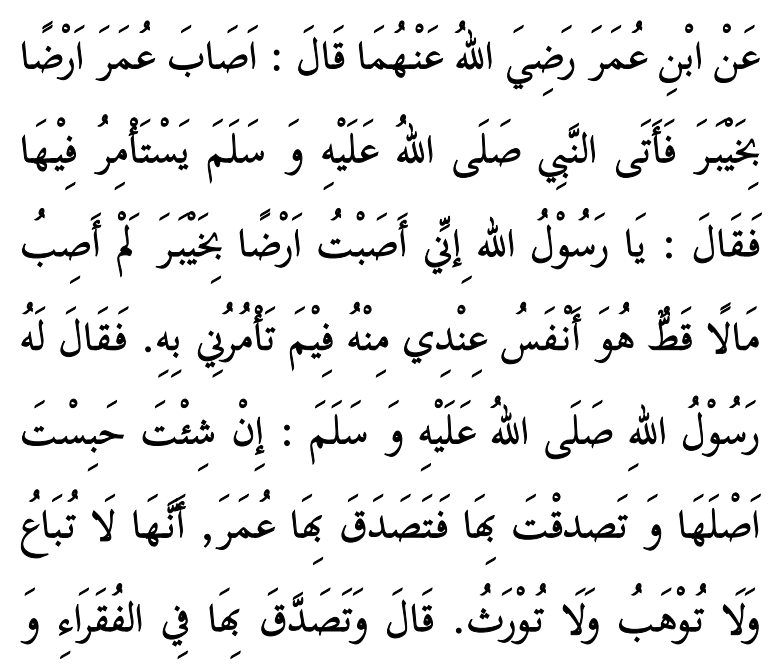

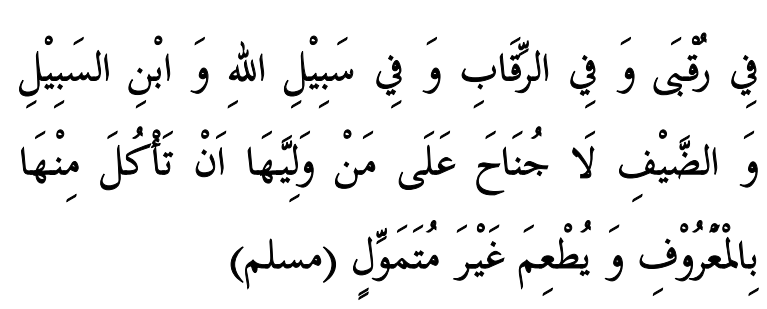

"Dari Ibnu Umar ra berkata bahwa sahabat Umar ra memperoleh sebidang tanah di Khaibar, kemudian menghadap kepada Rasulullah untuk memohon petunjuk. Umar berkata "Ya Rasulullah, saya mendapatkan sebidang tanah di Khaibar, saya belum pernah mendapatkan harta sebaik itu, maka apakah yang engau perintahkan kepadaku?" Rasulullah menjawab, "bila kamu suka, kamu tahan tanah itu, dan kamu sedekahkan hasilnya." Kemudian Umar melakukan shodaqoh, tidak dijual, tidak dihinahkan dan tidak pula diwariskan. Berkata Ibnu Umar, "Umar menyedekahkannya kepada orangorang miskin, kaum kerabat, budak belian, sabilillah, ibnu sabil dan tamu. Dan tidak mengapa dan tidak dilarang bagi yang menguasai (mengurus) tanah wakaf itu makan dari hasilnya dengan cara yang baik atau dengan tidak bermaksud mengumpulkan harta"."

Meskipun ayat dan hadis yang membahas mengenai wakaf tidak banyak, namun ayat dan hadist tersebut merupakan landasan pelaksanaan wakaf sejak zaman Rasulullah dan khulafaur rasyidin. Namun sejak masa khulafaur rasyidin, telah banyak dilakukan ijtihad mengenai hukum-hukum wakaf dalam Islam dengan menggunakan berbagai metode ijtihad.

\section{Permasalahan dan Konsep Pengembangan Wakaf Tunai di Indonesia}

Terdapat perbedaan ulama tentang unsur "keabadian". Perbedaan tersebut mengemuka khususnya antara madzhab Imam Syafi'i dan Hanafi serta madzhab Maliki. Imam Syafi'i misalnya sangat menekankan wakaf pada fixed asset (harta tetap) sehingga menjadikannya sebagai syarat sah wakaf. Mengingat di Indonesia secara fikih kebanyakan adalah pengikut madzhab Syafi'i maka bentuk wakaf yang lazim dilaksanakan adalah berupa tanah, masjid dan aset tetap lainnya ${ }^{12}$ Sedangkan imam Maliki mengartikan "keabadian" lebih pada nature barang yang diwakafkan baik itu aset tetap atau aset bergerak. Untuk aset tetap seperti tanah unsur keabadian ter-

$\overline{12 \text { Anshori, Hukum, h. } 95 .}$ 
penuhi karena memang tanah dapat dipakai selama tidak ada bencana alam yang bisa menghilangkan fisik tanah tersebut, begitu juga dengan benda-benda tetap lainnya seperti masjid. Namun berbeda dengan imam Syafi'i, imam Maliki memperlebar wilayah wakaf mencakup barang bergerak lainnya seperti wakaf buah tanaman tertentu. Substansi wakaf disini adalah pohon, sementara manfaat yang diambil adalah buah. Dalam pandangan madzhab ini "keabadian" wakaf adalah relatif tergantung pada umur rata-rata aset yang diwakafkan. Dengan demikian, kerangka pemikiran madzhab Maliki ini telah membuka luas kesempatan untuk memberikan wakaf dalam jenis aset apapun termasuk uang. Pada wakaf uang, uang dijadikan sebagai modal usaha kemudian menyalurkan keuntungannya sebagai wakaf ${ }^{13}$.

Salah satu model yang dapat dikembangkan dalam mobilisasi wakaf tunai adalah Model Dana Abadi, yaitu dana yang dihimpun dari berbagai sumber dengan berbagai cara yang sah dan halal, kemudian dana yang terhimpun dengan volume besar, diinvestasikan dengan tingkat keamanan yang tinggi melalui lembaga penjamin syariah. ${ }^{14}$ Mengacu pada Model Dana Abadi tersebut, konsep WakafTunai dapat diberlakukan dengan beberapa penyesuaian yang diperlukan, karena terdapat persoalan yang melekat pada Wakaf Tunai, yaitu problem of perpetuity ${ }^{15}$. Dan salah satu upaya preventifnya adalah dengan menegaskan tujuan Wakaf Tunai tersebut secara jelas, demikian juga dengan langkah-langkah yang dilalui juga harus dinyatakan dengan jelas dan mudah untuk dipahami.

Dalam penerapannya, Wakaf Tunai yang mengacu pada Model Dana Abadi dapat menerbitkan Sertifikat Wakaf Tunai dengan moninal yang berbedabeda sesuai dengan kemampuan sasaran yang dituju, sehingga dapat menjangkau segmen masyarakat yang beragam.

Tujuan dari penerbitan Sertifikat Wakaf Tunai ${ }^{16}$ adalah : a) Melengkapi perbankan Islam dengan produk Wakaf Tunai yang berupa sertifikat berdenominasi tertentu yang diberikan kepada para waqif sebagai bukti keikutsertaan, b) Membantu penggalangan dana sosial melalui Sertifikat Wakaf Tunai yang dapat diatasnamakan orang-orang tercinta, baik yang masih hidup, maupun yang telah meninggal sehingga dapat memperkuat integrasi kekeluargaan

\footnotetext{
13 Anshori, Hukum, h. 95-96.

14 Direktorat Pemberdayaanan Wakaf, Strategi, h. 9.

15 Maksudnya adalah persoalan yang berkaitan dengan keabadian selamanya pada dana pokok wakaf tunai tersebut

16 Nazir, Ensiklopedi, h. 589-590.
}

diantara umat, c) Meningkatkan investasi sosial dan mentransformasikan tabungan sosial menjadi modal sosial dan membantu pengembangan pasar modal sosial, d) Menciptakan kesadaran orang kaya terhadap tanggung jawab sosial mereka terhadap masyarakat sekitarnya sehingga kedamaian dan keamanan sosial dapat tercapai.

Dalam pedoman pemberdayaan wakaf tunai yang dirancang oleh Direktorat Pemberdayaan Wakaf, Departemen Agama Republik Indonesia, tidak ditemui adanya contoh konkret dari bentuk sertifikat wakaf tunai. Namun isi dari sertifikat ini mengacu pada sertifikat wakaf tunai yang diterbitkan oleh SIBL di Bangladesh. Dalam aturan perundangundangan Indonesia, ketentuan yang mengatur isi yang termuat dalam sertifikat wakaf tunai terdapat pada pasal 26 PP Nomor 42 Tahun 2006.

\section{Pengaturan Wakaf Tunai dalam Peraturan Per- undangan-Undangan di Indonesia}

Dalam Undang-undang Wakaf, wakaf dilaksanakan dengan memenuhi unsur wakaf sebagai berikut $^{17}$ : a. Waqif; b. Nazhir; c. Harta benda wakaf; d. Ikrar wakaf; e. Peruntukan harta benda wakaf; f. Jangka waktu wakaf.

Dalam peraturan perundang-undangan Republik Indonesia, pengaturan wakaf tunai ini berlandaskan kepada Keputusan Komisi Fatwa Majelis Ulama Indonesia tentang Wakaf Uang yang ditetapkan tanggal 11 Mei 2002 dan dituangkan dalam Undangundang Nomor 41 tahun 2004 dan pedoman pelaksanaan undang-undang tersebut berdasarkan kepada Peraturan Pemerintah Nomor 42 Tahun 2006 tentang Pelaksanaan Undang-Undang Nomor 41 Tahun 2004 tentang Wakaf Tunai. Mengenai peruntukan harta wakaf, UU Nomer 41 Tahun 2004, pasal 22 menyatakan bahwa harta benda wakaf hanya dapat diperuntukan bagi : a. sarana dan kegiatan ibadah; b. sarana dan kegiatan pendidikan serta kesehatan; c. bantuan kepada fakir miskin, anak terlantar, yatim piatu, beasiswa; d. kemajuan dan peningkatan ekonomi umat; dan/atau e. kemajuan kesejahteraan umum lainnya yang tidak bertentangan dengan syariah dan peraturan perundang-undangan.

Peruntukan harta wakaf ditetapkan dalam ikrar wakaf oleh waqif, namun apabila waqif tidak menyatakannya, maka Nadhir dapat menetapkan peruntukannya sesuai dengan tujuan dan fungsi wakaf sebagaimana yang ditentukan dalam undang-undang wakaf.

17 Undang-undang No. 41 tahun 2004 tentang wakaf, pasal 16 


\section{Rukun dan Macam-macam Wakaf Tunai}

Pada dasarnya rukun dan syarat wakaf uang adalah sama dengan rukun dan syarat wakaf tanah. Adapun rukun wakaf uang ${ }^{18}$ yaitu: 1 . Ada orang yang berwakaf (al-Waqif), 2. Ada harta yang diwakafkan (al-mauquf), 3. Ada tempat ke mana diwakafkan harta itu/tujuan wakaf (al-mauquf 'alaih), dan 4. Ada akad /pernyataan wakaf (as-sighat). Rukun wakaf tersebut harus memenuhi syaratnya masingmasing, yaitu: 1) Wakaf harus dilakukan secara tunai, tanpa digantungkan kepada akan terjadinya sesuatu peristiwa dimasa yang akan datang, sebab pernyataan wakaf berakibat lepasnya hak milik seketika setelah Waqif menyatakan berwakaf, 2) Tujuan wakaf harus jelas, maksudnya hendaklah wakaf itu disebutkan dengan terang kepada siapa diwakafkan.

Ditinjau dari segi peruntukkannya, wakaf terdiri atas dua macam, yaitu : a) Wakaf Ahli, yaitu wakaf yang ditujukan kepada orang-orang tertentu, seorang atau lebih, keluarga waqif atau bukan. Wakaf ini sering disebut juga dengan wakaf adz-Dzurri. ${ }^{19}$ Orang-orang yang berhak mengambil manfaat dari wakaf ini adalah orang-orang yang ditunjuk dalam pernyataan wakaf. Wakaf ini disebut juga sebagai wakaf 'ala al-aulad ${ }^{20}$, b) Wakaf Khoiri, yaitu wakaf yang secara tegas ditujukan untuk kepentingan agama atau masyarakat. Maka dari segi manfaat penggunaannya, benda wakaf tersebut terasa kemanfaatannya bagi kemanusiaan, bukan sekedar bagi keluarga dan kerabat. ${ }^{21}$

Dalam praktek wakaf, wakaf terdiri dari wakaf al-muhtlaq dan wakaf al-muqayyad. Wakaf al-muthlaq adalah praktek wakaf di mana waqif menyerahkan sepenuhnya kepada si waqif untuk mengelolanya tanpa batas. Adapun wakaf muqayyad adalah wakaf di mana waqif mensyaratkan agar harta yang diwakafkan itu hanya boleh dikelola dengan cara tertentu dan diberikan kepada pihak tertentu.

\section{Hasil dan Pembahasan}

\section{Pendekatan Nadhir kepada Waqif di Masjid Darush Sholikhin Kota Batu}

Pihak panitia pembangunan masjid menyatakan bahwa pembangunan masjid baru Darush Sholikhin diperlukan karena kondisi masjid yang tidak dapat menampung jumlah jama'ah ketika dilaksanakan sholat jum'at dan kondisi fasilitas masjid yang di-

\footnotetext{
18 Abdul Ghofir Anshori, Hukum dan Praktik Perwakafan di Indonesia, (Yogyakarta : Pilar Media, 2005), h. 94-95.

19 Direktorat Pemberdayaan Wakaf, Paradigma, h. 14.

20 Sayyid Sabiq, Fiqhu As Sunnah (Labanon : Dar Al 'Aroby,t.th), h. 378.

21 Direktorat Pemberdayaanan Wakaf, Figh, h. 16-17.
}

anggap kurang memadai dengan tidak adanya tempat parkir. Selain itu, lahan yang ada di samping lahan masjid lama juga telah dibeli masyarakat di sekitar masjid dan diwakafkan, yang menurut kesepakatan masyarakat akan digunakan untuk perluasan lahan masjid dan pembangunan masjid Darush Sholikhin.

Dalam hal perolehan lahan yang digunakan sebagai area perluasan masjid yang juga merupakan lokasi pembangunan masjid baru, masyarakat yang melakukan pembelian tanah tersebut bukan hanya berasal dari Kota Batu, melainkan dari luar Kota Batu, dengan mekanisme terima wakaf dari umat muslim. Fanani menyatakan, "pembelian tanah masjid dapat dilunasi sekitar tiga tahun yang lalu. ${ }^{22}$ ",

Pembangunan masjid baru yang dimulai sejak 19 Februari 2010, terkendala keuangan, yaitu dana yang ada tidak mencukupi untuk menyelesaikan pembangunan masjid sehingga pembangunan masjid baru Darush Sholikhin terancam berhenti dan tidak terselesaikan. Sebelum dipasang baleho "masjid dijual" pada tanggal 9 Juni 2011, yang bertepatan dengan hari kamis, panitia pembangunan masjid telah memasang spanduk "terima sumbangan" dari umat muslim untuk pembangunan masjid. Namun masyarakat kurang antusias dengan pemberitahuan tersebut, sehingga panitia membuat suatu inisiatif untuk menarik dana dari masyarakat muslim. Dengan banyaknya istilah sumbangan maupun wakaf yang tidak lagi dapat menarik perhatian masyarakat untuk memberikan bantuan dana, maka panitia menggunakan istilah "jual masjid" dalam penggalangan dana dari masyarakat muslim, selain juga untuk mengetuk hati dan kesadaran umat untuk bersama-sama membangun masjid.

Secara umum, pengertian dan pemahaman terhadap jual beli memberikan akibat hukum berupa pengalihan kepemilikan dari pihak penjual kepada pihak pembeli. Sebagaimana yang dinyatakan dalam Undang-Undang Nomor 20 Tahun 2000 Tentang Perubahan Atas Undang-Undang Nomor 21 Tahun 1997 pasal 2 ayat (2) dan KHES pasal 18. Namun penggunaan kata jual beli di masjid Darush Sholikhin ini merupakan jual beli yang terdapat dalam Al-Qur'an, tepatnya pada ayat surat Ali Imran ayat 92 dan surat At Taubah ayat 111, sehingga definisi jual beli yang ada di Darush Sholikhin akan sangat berbeda dengan definisi yang ada dan berkembang dalam masyarakat secara umum, baik dari segi ekonomi maupun segi

\footnotetext{
22 Muhammad Fanani. Wawancara. Kamis, 27 Oktober 2011, di kediaman Bpk Fanani, jam 14.15
} 
hukum, baik hukum perundangan Indonesia maupun fiqh muamalah. ${ }^{23}$

Meskipun berlandaskan pada Al-Qur'an dan Sunnah, jual beli yang banyak dibahas dalam Fiqh muamalah adalah jual beli baina an-nas. Dr. Raghib As-Sirjani dan Amru Khalid, dalam bukunya menyatakan bahwa mereka telah menemukan delapan ayat yang membahas tentang suatu perdagangan antara Allah dengan hamba-hamba-Nya. ${ }^{24}$ Diantara ayat tersebut adalah ayat yang terdapat dalam Surat At-Taubah ayat 20 , ayat 44 , dan ayat 111 , surat Ali Imran ayat 133-134, Al Baqarah ayat 207 dan Ali Imran ayat 92. Dalam ayat-ayat tersebut, dinyatakan bahwa jual beli antara Allah dengan orang-orang mukmin adalah transaksi surga dan peninggian derajat yang merupakan milik Allah dengan harta dan nyawa kaum mukminin tersebut. Adapun yang termasuk dalam transaksi ini adalah infak, shadaqah dan wakaf. Maka dapat ditarik kesimpulan, bahwa transaksi jual beli dengan berlandaskan Al-Qur'an terdapat dua macam, yaitu jual beli antara Allah dengan hambahamba-Nya dan jual beli antara manusia.

Dengan melihat pada landasan atau dasar yang digunakan dalam jual beli di Masjid Darush Sholikhin adalah surat Ali Imran ayat 92 dan At-Taubah ayat 111, yang merupakan ayat-ayat yang disebutkan oleh Dr. Raghib As Sirjani dan Amru Khalid, maka jual beli yang dilakukan ini merupakan jenis jual beli dalam Al-Qur'an yang terjadi antara hamba-hamba Allah dengan Allah, yang secara umum dikategorikan dalam bentuk ibadah dari pada muamalah. Sehingga jual beli yang terjadi di masjid Darush Sholikhin adalah jual beli antara umat muslim dengan Allah, sebagaimana yang ada dalam surat At-taubah ayat 111, dan panitia pembangunan masjid Darush Sholikhin hanya berperan sebagai fasilitator atau penghubung antara pembeli dan penjual, yaitu umat Islam yang membeli masjid tersebut dengan Allah sebagai pemilik masjid.

Dalam rangka mobilisasi dana wakaf tunai, berbagai pendekatan perlu dilakukan kepada waqif, sebagai pemilik dana, baik oleh pemerintah ataupun nadhir untuk mengetuk hati waqifin sehingga mau melakukan perwakafan. Pendekatan kepada calon Waqif tersebut, sebagaimana dirumuskan oleh Direktorat Pemberdayaan Wakaf, Departemen Agama Republik Indonesia berupa : 1. Pendekatan Keagamaan, 2.

\footnotetext{
23 Fanani, Wawancara, Kamis, 27 Oktober 2011, di kediaman Bpk Fanani, jam 14.15

24 Raghib As-Sirjani dan Amru Khalid, Siapa Membeli Surga, (Cet. 3. Solo : Aqwam, 2007), h. 70-76.
}

Pendekatan Kesejahteraan Sosial, 3. Pendekatan Bukti Keberhasilan Pengelolaan, dan 4. Pendekatan Efektifitas Pemanfaatan Hasil. ${ }^{25}$

Dengan mengetahui problematika pendekatan terhadap waqif yang ada di masjid Darush Sholikhin, maka dapat disimpulkan bahwa pendekatan yang dilakukan oleh pihak nadzir terhadap para waqif adalah pendekatan keagamaan dan pendekatan efektifitas pemanfaatan hasil dari wakaf tunai yang diterima oleh nadzir masjid Darush Sholikhin.

Pola pendekatan keagamaan perlu digiatkan oleh para agamawan kepada umat islam yang memiliki kemampuan finansial agar mau mewakafkan sebagian hartanya. Bentuk pendekatannya dibutuhkan kearifan dan metode yang tepat sehingga lebih menyentuh kepada para calon waqif, seperti keteladanan dan amanah. Dan pendekatan efektifitas pemanfaatan hasil dari wakaf tunai yang diterima oleh nadzir masjid Darush Sholikhin dengan penggunaannya secara langsung untuk pembangunan masjid Darush Sholikhin sehingga para waqif dan calon waqif semakin tergerak hatinya untuk menyumbangkan sebagian harta sebagai wakaf dalam rangka membantu terhadap problem-problem sosial yang ada disekitar para waqif dan calon waqif.

\section{Mekanisme Pelaksanaan Wakaf Tunai}

Pengelolaan wakaf tunai di Indonesia dilakukan melalui Lembaga Keuangan Syariah yang ditunjuk oleh Menteri. Hal ini diatur dalam Undang-Undang Wakaf Nomor 41 Tahun 2004 dan peraturan pelaksananya, yaitu PP nomor 42 tahun 2006. Pasal 22 dalam PP Nomor 42 tahun 2006 menyatakan bahwa uang yang dapat diwakafkan adalah mata uang rupiah. Apabila uang yang akan diwakafkan masih dalam mata uang asing, maka harus dikonversi terlebih dahulu ke dalam rupiah. ${ }^{26}$

Mekanisme wakaf tunai dalam PP No 42 Tahun 2006 adalah sebagai berikut : Pertama, waqif yang akan mewakafkan uangnya diwajibkan untuk: a. hadir di Lembaga Keuangan Syariah Penerima Wakaf Uang (LKS-PWU) untuk menyatakan kehendak wakaf uangnya; $b$. menjelaskan kepemilikan dan asal-usul uang yang akan diwakafkan; c. menyetorkan secara tunai sejumlah uang ke LKS-PWU; d. mengisi formulir pernyataan kehendak waqif yang berfungsi sebagai akta ikrar wakaf. Kedua, dalam hal waqif tidak dapat hadir, maka waqif dapat menunjuk wakil atau kuasanya. Ketiga, waqif dapat menyatakan ikrar

25 Direktorat, Manajemen, h. 17-21.

26 PP No. 42 Tahun 2006 pasal 22 ayat (1) dan (2) 
wakaf uang kepada nazhir di hadapan PPAIW yang selanjutnya nazhir menyerahkan akta ikrar wakaf tersebut kepada Lembaga Keuangan Syariah yang ditunjuk oleh Menteri ${ }^{27}$.

Keempat, LKS Penerima WakafUang bertugas ${ }^{28}$ : a. mengumumkan kepada publik atas keberadaannya sebagai LKS Penerima Wakaf Uang; b. menyediakan blangko Sertifikat Wakaf Uang; c. menerima secara tunai wakaf uang dari waqif atas nama nazhir; d. menempatkan uang wakaf ke dalam rekening titipan (wadi'ah) atas nama nazhir yang ditunjuk waqif; e. menerima pernyataan kehendak waqif yang dituangkan secara tertulis dalam formulir pernyataan kehendak waqif; f. menerbitkan Sertifikat Wakaf Uang serta menyerahkan sertifikat tersebut kepada waqif dan menyerahkan tembusan sertifikat kepada nazhir yang ditunjuk oleh waqif; dan g. mendaftarkan wakaf uang kepada Menteri atas nama nazhir.

Dalam pelaksanaan wakaf tunai di masjid Darush Sholikhin Kota Batu, Nadhir menerapkan mekanisme sebagai berikut :

Pertama, panitia memberikan penjelasan kepada calon nadzir mengenai jual beli di Darush Sholikhin. Dalam pelaksanaan wakaf tunai di Masjid darush Sholikhin ini, biasanya pendatang atau pengunjung akan menanyakan apa yang terjadi dan apa alasan adanya penjualan masjid tersebut. Tidak jarang pengunjung langsung menyatakan kekecewaannya dengan adanya masjid dijual tersebut. Sehingga panitia yang ada akan menjelaskan alasan atau latar belakang terjadinya penjualan masjid tersebut dan apa yang di maksud dengan jual beli yang terjadi di Darush Sholikhin beserta dengan landasan ayat yang digunakan dan pemikiran pihak panitia pembangunan masjid Darush Sholikhin terhadap ayat tersebut. Tahapan ini bisa disebut sebagai tahap penginformasian kepada calon waqif, sehingga waqif memahami dan mengerti apa yang terjadi di masjid Darush Sholikhin.

Kedua, Calon waqif memutuskan untuk mewakafkan uangnya atau tidak. Ketika pendatang atau pengunjung tersebut telah mendapat kejelasan, tidak jarang pengunjung tersebut menyatakan ingin ikut berpartisipasi dengan membeli masjid yang dijual tersebut tanpa adanya paksaan dari panitia pembangunan masjid Darush Sholikhin maupun dari nadzir masjid. Ketika calon waqif berpartisipasi dalam pembangunan masjid, panitia tidak memberikan patokan seberapa luas masjid yang harus

27 PP No. 42 Tahun 2006, pasal 23

28 PP No. 42 Tahun 2006, pasal 25 dibeli atau besar dana yang harus diserahkan untuk wakaf, meskipun dalam spanduk dan baleho yang terpampang di depan masjid tertulis harga permeter persegi, sehingga pembelian masjid tersebut sesuai dengan kemampuan pembeli dan tidak membebani atau memberatkannya. Hal ini sesuai dengan petunjuk pelaksanaan wakaf yang diberikan oleh Direktorat Pemberdayaan Wakaf, dimana waqif dapat memberikan wakafnya tanpa ada batasan nilai wakafnya. ${ }^{29}$

Bagi calon waqif yang tidak melakukan perwakafan, maka mekanisme yang terjadi hanyalah sampai pada pemberian informasi mengenai jual beli masjid di masjid Darush Sholikhin, Kota Batu, sedangkan bagi calon waqif yang menyatakan bergabung dalam jual beli masjid tersebut, maka bagi calon waqif tersebut berlaku mekanisme jual beli masjid hingga tuntas. ${ }^{30}$

Ketiga, Serah terima dana wakaf dari waqif kepada panitia pembangunan masjid, sebagai wakil dari nadzir. Dalam hal wakaf ada dua macam, yaitu wakaf ahli dan wakaf khoiri, maka hal ini harus dibedakan dengan jelas dalam ikrar wakafnya. Hal ini diatur dalam angka romawi 1 (I) umum, poin ketiga, penjelas Peraturan Pemerintah No. 42 Tahun 2006. Namun dikarenakan peruntukan wakaf yang ditujukan untuk masjid maka sudah jelas wakaf tersebut merupakan wakaf khoiri. Dan dalam jangka waktu wakaf, karena tujuan dari penggunaan dana wakaf tersebut adalah untuk pembangunan masjid, maka wakaf di Darush Sholikhin ini termasuk dalam wakaf al-muabbad atau wakaf tidak terbatas dan bukan wakaf al-muqayyat. ${ }^{31}$

Dalam setiap transaksi muamalah, syariah mensyaratkan adanya ijab qabul. Dalam hal pelaksanaan wakaf tunai di masjid Darush Sholikhin ini, akad ijab-nya adalah "Bismillahirrohmanirrohim. Saya, (nama waqif), menyerahkan uang sebesar (jumlah uang yang diberikan untuk wakaf) kepada nadzir, untuk digunakan dalam pembangunan masjid Darush Sholikhin", yang dijawab oleh panitia penerima uang tersebut dengan qabul, "Bismillahirrohmanirrohim. Telah saya terima, uang senilai (jumlah yang diberikan untuk wakaf) atas nama nadzir untuk pembangunan masjid Darush Sholikhin”. Dengan adanya ijab qabul ini, maka transaksi yang dilakukan menjadi jelas dan menurut syariat sah hukumnya.

\footnotetext{
29 Direktorat Pemberdayaanan Wakaf, Strategi, h. 9.

30 Calon waqif yang memilih untuk melakukan perwakafan akan melalui tahapan-tahapan yang ada dalam mekanisme jual wakaf tunai dalam jual masjid di Darush Sholikhin.

31 Penjelasan Peraturan Pemerintah No. 42 Tahun 2006, Pasal 26 huruf f.
} 
Dan keberadaan saksi dalam akad tersebut, panitia menghadirkan anggota panitia yang lain, untuk turut hadir dalam serah terima wakaf atau jual beli masjid tersebut. Jumlah saksi minimal, sebagaimana yang ditentukan oleh Undang-Undang adalah dua orang, maka yang hadir untuk menyaksikan serah terima tersebut adalah minimal dua orang. Namun terkadang hal ini sulit untuk dilaksanakan di Darush Sholikhin. Tidak jarang pembeli masjid hanya mampir sebentar untuk menyerahkan uang atau menitipkan kepada jama'ah masjid untuk diserahkan kepada panitia. Masyarakat yang seperti ini, yang sifatnya masih tradisional, tidak mau namanya dicatat oleh panitia sehingga panitia mencantumkan kata "hamba Allah" dalam data yang diarsipkan oleh panitia. Maka jelas dengan keadaan masyarakat yang demikian, penghadiran saksi sejumlah dua orang terkadang tidak dapat dilaksanakan dengan baik di Darush Sholikhin.

Selanjutnya waqif menuliskan datanya yang terdiri dari nama, alamat yang dapat dituju, jumlah dana yang diberikan, luas masjid yang dibeli, dan nomer telepon yang dapat dihubungi. Hal ini untuk pengadministrasian data waqif dan jumlah luas masjid yang telah terjual. Selain itu, untuk memudahkan pihak panitia dalam memberikan informasi tentang perkembangan pembangunan masjid atau menginformasikan bila masjid telah terbangun dengan sempurna. Data ini kemudian dimasukkan dalam data komputer untuk mengetahui jumlah waqif dan jumlah luas masjid yang telah terjual.

\section{Penerbitan sertifikat wakaf tunai.}

Pada ketentuan dalam Undang-undang No. 41 tahun 2004 pasal 29, pada ayat (1) diatur bahwa wakaf benda bergerak berupa uang dilaksanakan oleh waqif dengan pernyataan kehendak waqif yang dilakukan secara tertulis, sehingga pada ayat (2) pasal ini diatur mengenai penerbitan sertifikat wakaf uang sebagai pernyataan tertulis dari waqif.

Pada Peraturan Pemerintah No. 42 tahun 2006 yang merupakan pedoman pelaksanaan Undangundang No. 41 tahun 2004, dalam pasal 1 angka 7 menyatakan bahwa sertifikat wakaf uang adalah surat bukti yang dikeluarkan oleh Lembaga Keuangan Syari'ah kepada waqif dan nadzir tentang penyerahan wakaf uang. Dan yang dimaksud dengan Lembaga Keuangan Syari'ah adalah badan hukum Indonesia yang bergerak di bidang keuangan Syariah. ${ }^{32}$ Selain

32 Peraturan Pemerintah No. 42 tahun 2006, Pasal 1 angka 9. itu, Lembaga Keuangan Syari'ah (LKS) yang dapat menerima wakaf tunai adalah LKS yang ditunjuk oleh menteri. ${ }^{33}$ Maka jelas bahwa Undang-undang Wakaf, yang selanjutnya disebut dengan UUW, dan Peraturan Pemerintahnya mengatur pelaksanaan wakaf tunai yang dilakukan melalui lembaga keuangan syari'ah, sebagaimana ketentuan dalam pasal 43 UUW dengan tujuan untuk menjamin kekekalan dana karena lembaga tersebut dijamin oleh lembaga penjamin simpanan yang menjamin tidak akan terjadi dana habis atas dana wakaf tersebut, sehingga keberadaaanya bisa terus dipertahankan. Hal ini tentu saja sangat berbeda penerapannya dengan wakaf yang diberikan yang tujuannya telah jelas, sehingga dana tersebut jelas pengalokasian dan pemanfaatannya.

Dalam pasal 22 Undang-undang Wakaf (UUW) ditentukan peruntukan-peruntukan wakaf yang salah satunya adalah sarana dan kegiatan ibadah dalam rangka mencapai tujuan dan fungsi wakaf. Namun dalam Pasal 23 ayat (1) undang-undang ini, penetapan peruntukan harta benda wakaf dapat dilakukan oleh waqif pada pelaksanaan ikrar wakaf atau saat dilakukan serah terima secara langsung antara waqif dan nadzir.

Berdasarkan UUW dan PP No. 42 Tahun 2006, maka nadzir Darush Sholikhin merupakan nadzir perorangan, yang dalam pasal 10 UUW disyaratkan : a. warga negara Indonesia; b. beragama Islam; c. dewasa; d. amanah; e. mampu secara jasmani dan rohani; dan f. tidak terhalang melakukan perbuatan hukum, dan kesemuanya ini telah dipenuhi oleh nadzir masjid Darush Sholikhin, yang sebagian merupakan anggota panitia pembangunan masjid Darush Sholikhin. Mengenai definisi, pendaftaran dan jumlah anggota Nadzir perorangan ini diatur dalam pasal 4 PP No. 42 tahun $2006^{34}$.

Mengenai Sertifikat Wakaf Tunai, pihak Darush Sholikhin mengeluarkan "sertifikat waqaf pembangunan masjid" dan "kwitansi partisipasi aktif dalam pembangunan masjid Darush Sholikhin", karena wakaf tersebut ditujukan untuk pembangunan masjid Darush Sholikhin.

\footnotetext{
33 UU No. 41 Tahun 2004, pasal 28.

34 Isi pasal 4 PP No. 42 Tahun 2006 :

(1) Nazhir perseorangan ditunjuk oleh Wakif dengan memenuhi persyaratan menurut undang-undang.

(2) Nazhir sebagaimana dimaksud pada ayat (1) wajib didaftarkan pada Menteri dan BWI melalui Kantor Urusan Agama setempat.

(3) Dalam hal tidak terdapat Kantor Urusan Agama setempat sebagaimana dimaksud pada ayat (2), pendaftaran Nazhir dilakukan melalui Kantor Urusan Agama terdekat, Kantor Departemen Agama, atau perwakilan Badan Wakaf Indonesia di provinsi/kabupaten/kota.

(4) BWI menerbitkan tanda bukti pendaftaran Nazhir.
} 
Dalam aturan perundang-undangan Indonesia, dalam pasal 26 PP Nomor 42 Tahun 2006 dinyatakan bahwa dalam sertifikat wakaf tunai, sekurangkurangnya memuat : a. nama LKS Penerima Wakaf Uang; b. nama waqif; c. alamat waqif; d. jumlah wakaf uang; e. peruntukan wakaf; f. jangka waktu wakaf; g. nama nazhir yang dipilih; h. alamat nazhir yang dipilih; dan i. tempat dan tanggal penerbitan Sertifikat Wakaf Uang.

Dalam Sertifikat Wakaf Tunai yang dikeluarkan oleh Panitia Pembangunan masjid Darush Sholikhin Kota Batu tidak termuat di dalamnya 3 hal yang seharusnya ada dalam sertifikat wakaf yang sesuai dengan peraturan perundang-undangan Indonesia. 3 hal tersebut adalah : a. nama LKS Penerima Wakaf Uang; b. jangka waktu wakaf; c. alamat nazhir yang dipilih. Hal ini karena masjid Darush Sholikhin Kota Batu bukan lembaga yang bergerak di sektor keuangan sebagaimana Lembaga Keuangan Syariah. Mengenai jangka waktu wakaf, wakaf tunai di masjid Darush Sholikhin ini merupakan wakaf yang telah jelas jangka waktunya, yaitu wakaf muabbad atau wakaf selamanya, yang dari penggunaannya untuk pembangunan masjid Darush Sholikhin maka dana tersebut telah teralokasikan dan diwujudkan dalam bentuk fisik bangunan masjid Darush Sholikhin yang terletak di Kecamatan Temas, Kota Batu.

Dengan adanya ketentuan bahwa Nadzir wakaf merupakan orang yang berada di daerah terdapatnya wakaf, yang di sini adalah tanah tempat dibangunnya masjid Darush Sholikhin adalah tanah wakaf dari masyarakat di daerah Temas, Kota Batu, maka jelaslah bahwa alamat nadzir masih berada di Kota Batu, sehingga tidak perlu dilakukan pencantuman alamat nadzir atau panitia pembangunan masjid Darush Sholikhin.

Pemberian sertifikat wakaf tunai dan kwitansi partisipasi aktif dalam pembangunan masjid Darush Sholikhin, oleh panitia Sertifikat Wakaf diberikan kepada waqif yang memberikan uang senilai minimal Rp. 250.000,00 atau sebanding dengan pembelian masjid seluas $0,25 \mathrm{~m}^{2}$. Dan pada jumlah yang kurang dari itu, kepada setiap wakaf senilai Rp. 50.000,00 akan diberikan satu lembar kwitansi partisipasi aktif dalam pembangunan masjid Darush Sholikhin. Jumlah nominal yang tertera dalam sertifikat wakaf, tidak ditemukan jumlah nominal pasti ataupun batasan-batasan nominal pada Sertifikat tersebut, baik dalam UUW, PP No. 42 tahun 2006 maupun dalam buku-buku tentang wakaf yang disusun oleh Dirjen Pemberdayaan Wakaf, Departemen Agama Republik
Indonesia. Maka kebijakan yang dikeluarkan oleh Darush Sholikhin mengenai batasan nominal dalam pengeluaran sertifikat wakaf pembangunan masjid maupun kwitansi partisipasi aktif dalam pembangunan masjid Darush Sholikhin, Kota Batu, tidak bertentangan dengan peraturan perudangan ataupun kebijakan apapun di Indonesia.

Kebijakan panitia pembangunan masjid Darush Sholikhin dalam penerbitan sertifikat wakaf maupun penerbitan kwitansi partisipasi aktif dalam pembangunan masjid Darush Sholikhin ini bertujuan untuk memudahkan pengadministrasian yang dilakukan oleh pihak panitia. Dari sejumlah kwitansi yang diterbitkan, dana yang terkumpul diakumulasikan untuk dimasukkan dalam pengadministrasian sertifikat wakaf tunai dengan menggunakan satu nama, yaitu "hamba Allah". Maka jelaslah jumlah dana yang telah terkumpul dan jumlah luas masjid yang telah terjual.

Dalam pasal 3 UUW dinyatakan bahwa wakaf yang telah diikrarkan tidak dapat dibatalkan, maka dalam hal transaksi jual beli masjid ini merupakan transaksi yang waktunya tidak terbatas atau muabbad. Yang dengannya Allah telah memberikan jannah sebagai imbalan transaksi ini. Berdasarkan pada sifat perwakafannya yang tanpa batasan waktu, maka kepemilikan Allah atas wakaf tersebut juga kekal adanya. Maka dapat dikatakan bahwa kepemilikan Allah dalam jual beli ini adalah kepemilikan penuh. Dan kepemilikan tersebut tidak dapat dialihkan sebagaimana ketentuan-ketentuan yang ada dalam KUHPer, KHES maupun sumber hukum perundangan lainnya di Indonesia.

\section{Penggunaan dana wakaf tunai untuk pem- bangunan masjid Darush Sholikhin}

Dengan memperhatikan perbedaan-perbedaan yang ada dalam implementasi wakaf tunai yang terdapat dalam peraturan perundang-undangan tentang wakaf, pada pelaksanaan wakaf tunai di masjid Darush Sholikhin tidak ditemui mekanismemekanisme rumit sebagaimana yang diatur oleh pemerintah. Dan karena masjid Darush Sholikhin bukan merupakan lembaga yang bergerak di sektor keuangan, maka pelaksanaannya berbeda dengan mekanisme yang ada di LKS. Selain itu, dana yang merupakan wakaf tunai dari waqif langsung digunakan sebagaimana peruntukannya yang telah dinyatakan oleh waqif, yaitu untuk pembangunan masjid Darush Sholikhin, Kota Batu. Maka dapat disimpulkan bahwa pelaksanaan wakaf tunai yang terjadi di masjid Darush Sholikhin sebagaimana 
diuraikan pada pembahasan diatas merupakan pelaksanaan wakaf tunai secara sederhana.

\section{Kesimpulan}

Dari paparan di atas, dapat disimpulkan bahwa pelaksanaan wakaf tunai dalam pelaksanaan di masjid Darush Sholikhin merupakan pelaksanaan wakaf tunai secara sederhana atau tradisional, karena masjid Darush Sholikhin bukanlah lembaga pengembang dana wakaf, sebagaimana Lembaga Keuangan Syari'ah (LKS) yang mengelola dan mengembangkan dana wakaf tunai melalui berbagai sarana investasi yang tidak bertentangan dengan ketentuan syari'ah. Dalam hukum Islam, pelaksanaan wakaf tunai di masjid Darush Sholikhin ini adalah sah, namun dalam hukum perundang-undangan yang berlaku di Indonesia, pelaksanaan wakaf tunai ini tidak memiliki payung hukum sehingga bila timbul permasalahan dalam wakaf tunai ini tidak ada landasan hukum yang dapat digunakan

\section{DAFTAR PUSTAKA}

Al Kabisi, Muhammad Abid Abdullah. Hukum Wakaf. Jakarta : IlMan, 2003.

Anshori, Abdul Ghofir. Hukum dan Praktik Perwakafan di Indonesia. Yogyakarta : Pilar Media, 2005.

As-Sirjani, Raghib, Amru Khalid. Siapa Membeli Surga. Cet. 3. Solo : Aqwam, 2007.

Direktorat Pemberdayaan Wakaf. Fiqh Wakaf. Jakarta : Departemen Agama RI, 2007.

Paradigma Baru Wakaf di Indonesia. Jakarta :

\section{Saran}

Bagi akademisi, peneliti mengharapkan penelitian ini dapat dikembangkan lagi dengan sudut pandang ataupun metode yang berbeda. Dengan demikian kemanfaatan dari penelitian ini akan lebih dinikmati dan dirasakan oleh masyarakat dan juga diharapkan dapat menjadi masukan, dan referensi dalam pengembangan mengenai wakaf.

Bagi masyarakat sekitar masjid Darush Sholikhin selain melaksanakan hukum Islam dalam pelaksanaan wakaf tunai diharapkan juga memperhatikan perundang - undangan serta peraturan - peraturan terkait mengenai wakaf di Indonesia. Melihat kasus - kasus mengenai wakaf yang terjadi akibat tidak adanya perlindungan dari hukum. Hal ini sangat perlu diperhatikan karena perlindungan hukum dalam pelaksanaan wakaf sangat dibutuhkan, apalagi jika terjadi sengketa mengenai wakaf yang telah dilaksanakan.

Departemen Agama RI, 2007.

Pedoman Pengelolaan Wakaf Tunai. Jakarta : Departemen Agama RI, 2007.

Peraturan Pemerintah Nomor 42 Tahun 2006 Pelaksanaan Undang-Undang Nomor 41 Tahun 2004 tentang Wakaf

Strategi Pengembangan Wakaf Tunai di Indonesia. Jakarta : Departemen Agama RI, 2008.

Undang-undang Nomor 41 Tahun 2004 tentang Wakaf. 